\title{
PENERAPAN TEKNOLOGI MODIFIKASI CUACA (TMC) UNTUK MENGATASI KABUT ASAP AKIBAT KEBAKARAN LAHAN DAN HUTAN DI PROVINSI JAMBI SEPTEMBER-OKTOBER 2012
}

\author{
Djazim Syaifullah *)
}

\begin{abstract}
Intisari
Pelaksanaan Teknologi Modifikasi Cuaca (TMC) untuk mengatasi bencana asap akibat kebakaran lahan dan hutan di Propinsi Jambi telah dilakukan pada tanggal 07 September sampai dengan 06 Oktober 2012. Pelaksanaan operasi ini didukung oleh 1 (satu) unit pesawat CASA 212-200 dan telah melakukan penerbangan penyemaian selama 33 kali. Selama kegiatan TMC, hujan terjadi hampir setiap hari di berbagai tempat di wilayah Propinsi Jambi dengan intensitas yang bervariasi. Secara umum kondisi hotspot selama kegiatan TMC mengalami penurunan dibandingkan dengan periode sebelum dilaksanakannya TMC. Fluktuasi jumlah hotspot yang terjadi akibat fluktuasi keberadaan awan dan aktifitas pembakaran lahan. Pada akhir kegiatan, jumlah hotspot di wilayah Jambi sudah jauh berkurang, tetapi karena kondisi asap masih dirasa cukup pekat pada beberapa hari tertentu jang diduga berasal dari sebelah selatan Propinsi Jambi, maka kegiatan pelaksanaan TMC dilanjutkan di Propinsi Sumatera Selatan.
\end{abstract}

\begin{abstract}
The implementation of Weather Modification Technologies to cope with the disaster and umoke from forest fires in Jambi has been done on 07 September to 06 October 2012. The uperation was supported by 1 (one) unit of CASA 212-200 aircraft and has a flight seeding tor 33 times. During the activities, rainfall occur almost every day at various places in the zrovince of Jambi with varying intensity. Generally, the hotspot condition was decreased ampared with the period before the activities. Fluctuations in the number of hotspots that scour due to fluctuations in the presence of clouds and land burning activities. At the end of the activity, the number of hotspots in Jambi area were much reduced, but the condition is III considered fairly dense smoke on some days thought to have come from the southern zuince of Jambi, cloud seeding operation was continued in South Sumatra province.
\end{abstract}

Fanta Kunci : Bencana asap, Kebakaran lahan dan hutan, TMC.

\section{BICAHULUAN}

BHIino tahun 2012 telah diperkirakan ogi Dunia (WMO) kemungkinan de bulan Juli sampai dengan 2012. Hal ini diperkuat oleh Meteorologi, Klimatologi dan bahwa bulan Juli 2012 wilayah dalam fase El Nino lemah dan ngkat sampai fase moderat ondisi ini dapat menimbulkan di sejumlah daerah. Dampak sudah mulai dirasakan di wilayah Kalimantan sejak bulan Juli
2012, ditandai dengan munculnya titik panas (hotspot) dengan jumlah yang cukup tinggi.

Berdasarkan pemantauan hotspot dari data satelit National Oceanic and Atmospheric Administration (NOAA), terhitung sejak tanggal 1 Januari 2012 sampai dengan tanggal akhir Agustus 2012 di wilayah Indonesia terpantau hotspot mencapai sekitar 21 ribu titik yang sebarannya terkonsentrasi di wilayah Sumatera, Kalimantan dan Sulawesi.

Dengan memperhatikan pola historis kejadian hotspot di wilayah Sumatera dan Kalimantan, yang biasanya mencapai puncaknya pada periode bulan Agustus, September dan Oktober, Badan Nasional Penanggulangan Bencana (BNPB) bekerjasama dengan Unit Pelaksana Teknis (UPT) Hujan Buatan - Badan Pengkajian dan Penerapan Teknologi (BPPT) mengambil langkah antisipasi dengan 
melakukan operasi pemadaman kebakaran lahan dan hutan dari udara melalui pelaksanaan operasi penerapan Teknologi Modifikasi Cuaca (TMC) atau yang sering dikenal dengan istilah hujan buatan.

Teknologi Modifikasi Cuaca (TMC) adalah suatu bentuk upaya manusia dalam mengintervensi proses di dalam awan hujan (terutama awan jenis Cumulus). TMC memodifikasi proses tumbukan dan penggabungan butir air di dalam awan sehingga proses tumbukan dan penggabungan dapat dipercepat dengan menambahkan CCN (Cloud Condensation Nuclei) dalam bentuk garam halus (superfine) ke dalam awan yang akhirnya dapat meningkatkan intensitas curah hujan. Hujan yang turun di lokasi kebakaran dan sekitarnya diharapkan dapat membantu memadamkan sejumlah hotspot dan menipiskan kabut asap sehingga meningkatkan visibility (jarak pandang) yang sering mengganggu kesehatan dan aktivitas penerbangan udara.

Secara regulasi, peranan TMC untuk mitigasi bencana kebakaran lahan dan hutan telah tertuang dalam Instruksi Presiden Republik Indonesia Nomor 16 Tahun 2011 tentang Peningkatan Pengendalian Kebakaran Lahan dan hutan, dimana Presiden RI memberikan instruksi kepada Menteri Riset dan
Teknologi untuk melakukan koordinasi dalam pemberian bantuan penanganan kebakaran lahan dan hutan dengan menggunakan teknologi pembuatan hujan buatan.

Pelaksanaan operasi penerapan TMC di wilayah Sumatera tahun 2012 difokuskan di Provinsi Riau dan Propinsi Jambi, untuk Propinsi Jambi penempatan Posko TMC bertempat di wilayah Bandara Sultan Thaha Syaifuddin Jambi yang dilakukan selama 30 (tiga puluh) hari dimulai tanggal 07 September 2012. Pelaksanaan operasi ini didukung oleh 1 (satu) unit pesawat CASA 212200milik Tentara Nasional Indonesia Angkatan Darat (TNI-AD).

Tulisan ini melakukan kajian hasil pelaksanaan Teknologi Modifikasi Cuaca (TMC) untuk mengatasi asap akibat kebakaran lahan dan hutan di Propinsi Jambi pada bulan September - Oktober 2012, selain kajian hotspot dan jarak pandang (visibility).

\subsection{Daerah Kerja}

Daerah sasaran (target operasi) adalah seluruh wilayah Propinsi Jambi, seperti yang tergambarkan dalam Gambar 1 berikut ini

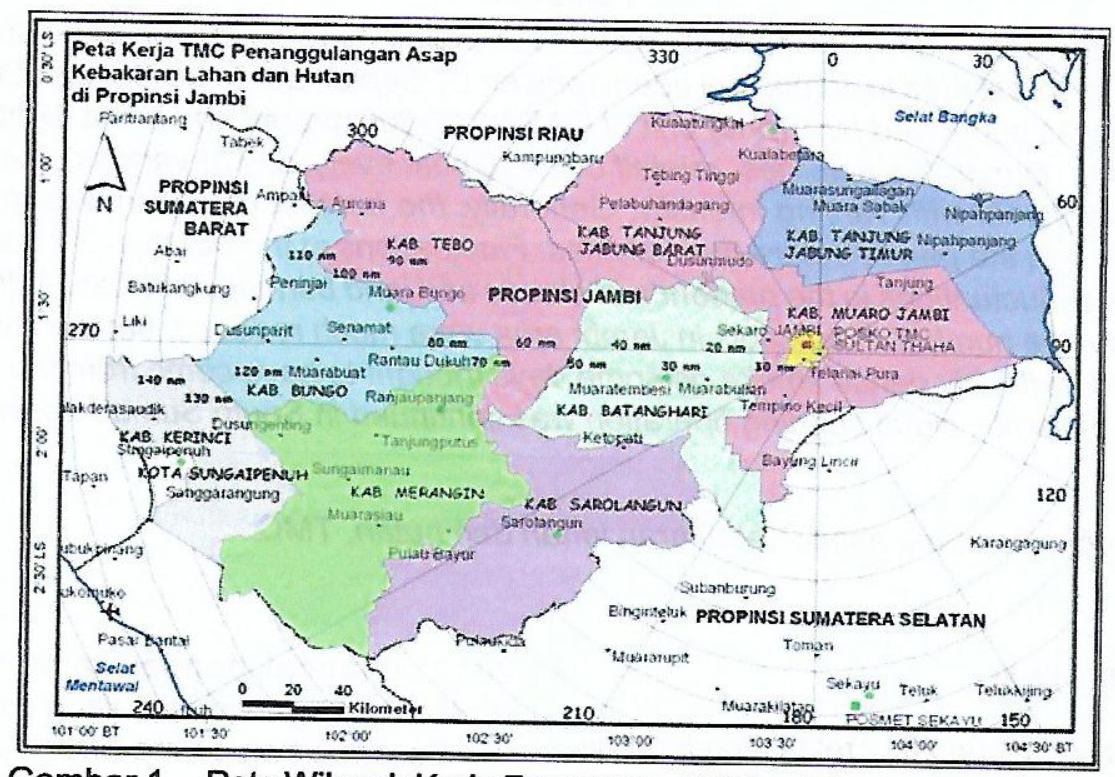

Gambar 1. Peta Wilayah Kerja Penerapan TMC untuk menanggulangi asap akibat kebakaran lahan dan hutan di Propinsi Jambi (diwarnai)

\subsection{Kondisi Cuaca Daerah Target}

Kondisi cuaca selama pelaksanaan Teknologi Modifikasi Cuaca (TMC) dari tanggal 7 September s.d. 6 Oktober 2012 di wilayah Jambi dipengaruhi oleh kondisi cuaca global/regional maupun lokal.

Kondisi cuaca global/regional yang dominan pengaruhnya selama periode kegiatan adalah adanya pengaruh IOD (Indian Ocean Dipole) positif yang berakibat kurangnya massa udara yang masuk ke wilayah Jambi. Massa udara dari Tenggara berasosiasi dengan minimnya pembentukan awan hujan di wilayah Jambi. Sedangkan massa udara yang datang dari dari Laut China Selatan dan Samudara Hindia berasosiasi dengan banyaknya pembentukan awan hujan di wilayah Jambi.

Faktor lain yang berpengaruh terhadap pembentukan awan hujan di wilayah Jambi adalah fenomena ENSO (EI Nino Southern Oscilation) dan MJO (Madden Julian Oscillation) serta gangguan tropis berupa depresi tropis (tropical depression) hingga siklon tropis (tropical cyclon) yang terjadi di Pasifik bagian Barat hingga Laut Cina Selatan maupun di Samudera Hindia sebelah barat 
Sumatera. Sirkulasi monsun Asia-Australia, Daerah Pertemuan Angin Antar Tropis atau Inter Tropical Convergence Zone (ITCZ) yang merupakan daerah pertumbuhan awan, serta kondisi suhu permukaan laut di sekitar wilayah Indonesia juga berpengaruh terhadap cuaca dan iklim di wilayah Sumatera Selatan.

Suhu muka laut pada bulan September 2012 ditunjukkan pada Gambar 2. Suhu muka laut di wilayah Indonesia selama periode kegiatan TMC di Jambi bervariasi antara $23^{\circ} \mathrm{C}$ hingga $34^{\circ} \mathrm{C}$. Perairan Indonesia sekitar equator umumnya lebih hangat dibandingkan dengan di perairan sebelah selatan Jawa dan Nusa Tenggara. Suhu muka laut di Pasifik equator bagian tengah selama bulan September lebih tinggi daripada rata-ratanya. Di daerah NINO 3.4 anomali temperatur muka laut berkisar antara $+0.5^{\circ} \mathrm{C}$ hingga $+1^{\circ} \mathrm{C}$. Kondisi ini menunjukkan bahwa selama bulan September hingga awal Oktober 2012 masih terjadi fenomena El Niño dengan intensitas lemah.

Perairan di sebelah Selatan Jawa hingga Tenggara Sumatera mengalami pendinginan dibandingkan dengan nilai rata-ratanya. Anomali negatif suhu muka laut di perairan tersebut dijumpai selama bulan September 2012 (Gambar 2 bawah), yang menyebabkan kurangnya aktivitas konveksi di wilayah Jambi.

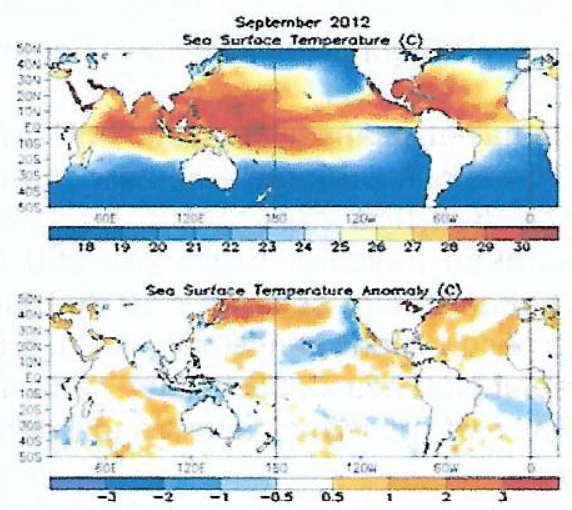

Gambar 2. Suhu muka laut (atas) dan anomali suhu muka laut (bawah) pada bulan September 2012

Sementara fenomena MJO tidak menunjukan adanya aktivitas konveksi di wilayah target. Pada Gambar 3. memperlihatkan pola anomali Outgoing Longwave Radiation (OLR) yang terjadi selama kegiatan TMC berlangsung. Warna biru pada gambar merupakan anomali negatif yang artinya terjadi peningkatan pertumbuhan awan konvektif di daerah tersebut, sedangkan warna merah menunjukkan anomali positif yang mengindikasikan kondisi kering. Berdasarkan analisis OLR umumnya terjadi adanya supresi curah hujan di wilayah Indonesia bagian selatan ekuator pada bulan September dan Oktober 2012.

Kondisi regional yang cukup mengganggu adalah munculnya tekanan rendah seperti

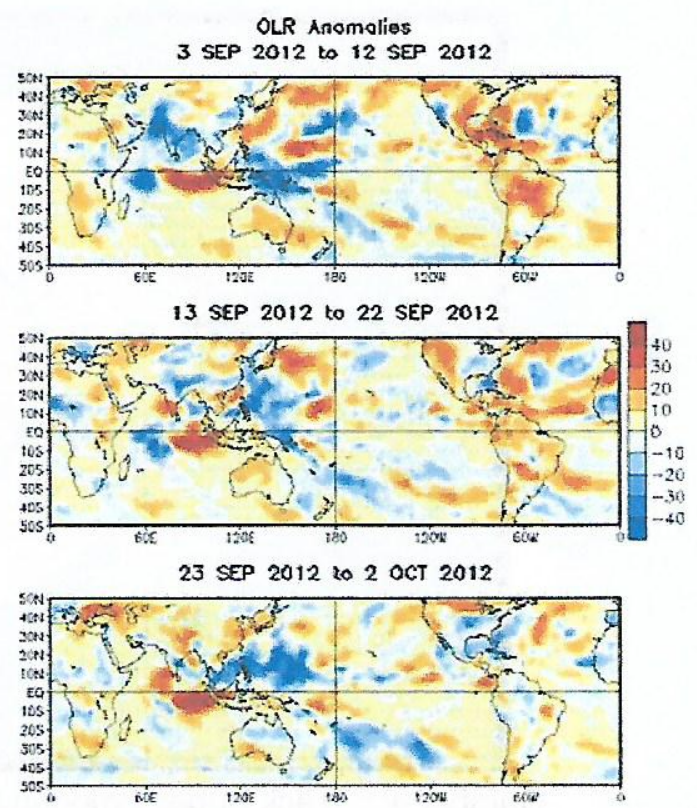

Gambar 3. Anomali OLR tanggal 3 September - 2 Oktober 2012. Pada periode ini aktifitas konveksi lemah di Jambi (diambil dari Climate Prediction Center / NCEP)

depresi tropis, badai tropis atau siklon tropis di sekitar wilayah Fillipina, Samudera Pasifik Barat Laut dan Laut Cina Selatan. Selama kegiatan berlangsung tercatat beberapa kejadian gangguan tropis yang berpengaruh terhadap supplai massa udara di wilayah target. Badai tropis "SANBA" yang terjadi pada tanggal 10-18 September 2012 mencapai kategori 4 (super typhoon) dengan pusat tekanan rendah $937 \mathrm{mb}$ dan kecepatan angin mencapai 315 $\mathrm{km} / \mathrm{jam}$.

Badai tropis "JELAWAT" (21 September - 2 Oktober) juga sudah mencapai tahap super typhoon dengan pusat tekanan rendah mencapai $918 \mathrm{mbar}$ dengan kecepatan angin mencapai $350 \mathrm{~km} / \mathrm{jam}$. Pada akhir bulan September sampai awal Oktober 2012 muncul siklon tropis "GAEMl" dengan pusat tekanan rendah mencapai 989 mbar dan kecepatan angin mencapai $130 \mathrm{~km} / \mathrm{jam}$. Gambar 4 berikut adalah salah satu contoh track typhoon dan prediksi beberapa hari ke depan.

Hingga akhir September 2012, posisi ITCZ masih berada di sekitar utara ekuator dan cenderung bergerak ke arah selatan mengikuti pergerakan tahunannya. Sedangkan kondisi suhu permukaan laut di sekitar Samudera Hindia sebelah barat Sumatra bagian Selatan hingga Selatan Jawa dengan anomali suhu berkisar $-0.5^{\circ} \mathrm{C} \mathrm{s} / \mathrm{d}-2^{\circ} \mathrm{C}$, berada di bawah nilai rata-rata atau normalnya. Sehingga pembentukan awan penghujan di Jambi dengan kondisi ini umumnya sulit terbentuk.

Setelah memasuki bulan Oktober 2012, kondisi menjadi berubah dimana suhu permukaan laut di sekitar Samudera Hindia sebelah barat Sumatera Bagian Selatan hingga Selatan Jawa anomali suhunya mulai menghangat bahkan ada 

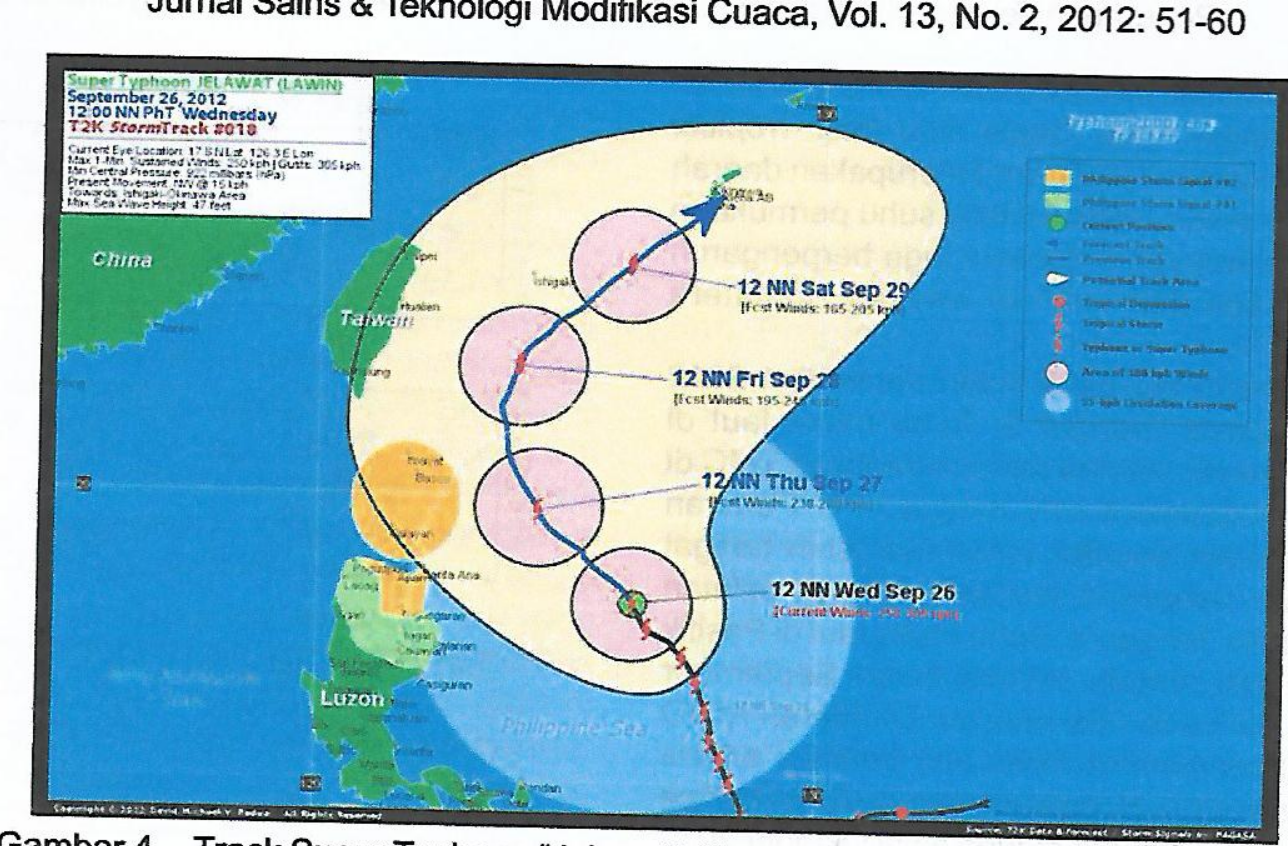

Gambar 4. Track Super Typhoon "Jelawat” ("Lawin”) yang terekam pada tanggal 26 September 2012 dan prediksi beberapa hari ke depan, Nampak typhoon masih menguat sampai dengan akhir September 2012.

yang mencapai $+1^{\circ} \mathrm{C}$. Kondisi ini terus berfluktuatif sehingga memudahkan untuk terjadinya pembentukan awan-awan di Jambi secara lokal seiring hilangnya gangguan tropis.

\section{PELAKSANAAN KEGIATAN}

Mengingat pertumbuhan awan di wilayah daerah target relatif lambat akibat adanya kabut asap, maka penerbangan pertama dilaksanakan sekitar jam 12.30 - 14.30 WIB. Penerbangan sorti kedua direncanakan sekitar jam 15.30 - 17.00 WIB. Penerbangan direncanakan 2 (dua) sorti setiap hari, namun realisasinya tergantung kondisi cuaca yang setiap saat selalu berubah. Penerbangan sorti terakhir diupayakan landing tidak melebihi jam 17.30 WIB (30 menit sebelum sunset).

Daerah penyemaian dan lintasan pesawat saat melakukan penyemaian selalu direkam

menggunakan alat navigasi GPS (Global Positioning System) yang dibawa oleh Flight Scientist. Pengoperasian GPS dimaksudkan untuk melihat tracking pesawat mulai onboard, saat melakukan penyemaian hingga pesawat kembali ke Posko, sehingga route dan manuver pesawat selama terbang terekam dengan baik. Pengoperasian GPS dilakukan oleh Flight Scientist selama penerbangan eksekusi.

Selama pelaksanaan kegiatan TMC di Propinsi Jambi, dari Posko Bandara Sultan Thaha telah dilakukan 33 (tiga puluh) kali penerbangan menggunakan pesawat Casa 212-200 dengan jumlah bahan semai sebanyak 32.000 kilogram. Realisasi penerbangan penyemaian awan di Propinsi Jambi selengkapnya dapat dilihat pada Tabel 1, sedangkan route penerbangannya dapat dilihat pada Gambar 5.

Tabel 1. Rekapitulasi Pelaksanaan Teknologi Modifikasi Cuaca untuk Penanggulangan Bencana Kabut Asap Akibat Kebakaran Lahan dan hutan di Propinsi Jambi Tahun 2012. Periode Tanggal 07
September s.d 06 Oktober 2012

\begin{tabular}{|c|c|c|c|}
\hline $\begin{array}{c}\text { Jumlah } \\
\text { Sorti }\end{array}$ & Daerah Seeding & $\begin{array}{c}\text { Total } \\
\text { Bahan } \\
\text { Semai } \\
(\mathrm{Kg})\end{array}$ & $\begin{array}{c}\text { Jumlah Hotspot } \\
\text { selama kegiatan }\end{array}$ \\
\hline 33 & $\begin{array}{c}\text { Kabupaten Batang Hari (11), Kabupaten Tanjung } \\
\text { Jabung Barat (7), Kabupaten Tanjung Jabung Timur } \\
\text { (10), Kabupaten Muara Jambi (5), Kabupaten } \\
\text { Sarolangun (3), Nipah Panjang (4), Tanjung (3), } \\
\text { Muara Bulian (2), Muara Sabak (2), Ketopati (1), } \\
\text { Dusun Mudo (1), Muara Tembesi (1), Kabupaten } \\
\text { Tebo (1), Tebing Tinggi (1), Tempino Kecil (1), } \\
\text { Kuala Betara (1), Kabupaten Muaro Bungo (1), } \\
\text { Kuala Tungkal (1) }\end{array}$ & 32.000 & $\begin{array}{c}\text { Tebo (99), Bungo (28), } \\
\text { Tanjung Jabung Barat } \\
\text { (46), Tanjung Jabung } \\
\text { Timur (63), Muaro } \\
\text { Jambi (70), Sarolangun } \\
\text { (83), Merangin (32), } \\
\text { Batang hari (37), } \\
\text { Kerinci (1) dan Sungai } \\
\text { Penuh (0) }\end{array}$ \\
\hline
\end{tabular}




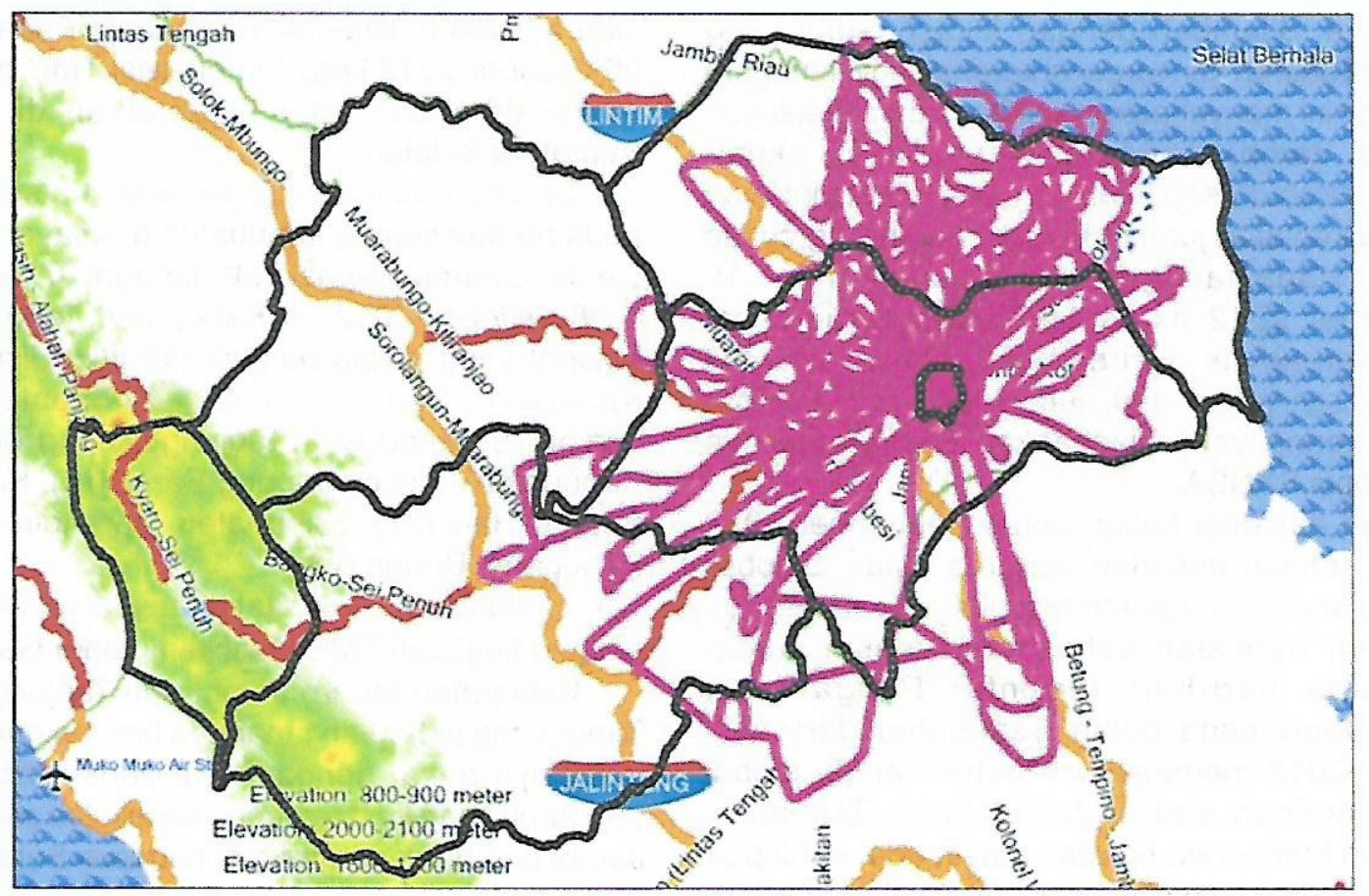

Gambar 5. Akumulasi route penyemaian awan di Propinsi Jambi (garis warna merah magenta) selama pelaksanaan TMC 07 September - 06 Oktober 2012

\section{HASIL DAN PEMBAHASAN}

Hasil kegiatan yang meliputi informasi kondisi titik panas (hotspot), kejadian hujan di daerah target, dan visibility di Jambi yang terjadi selama berlangsungnya kegiatan TMC dibahas dalam bab ini. Data hotspot yang digunakan bersumber dari Departemen Kehutanan RI, sementara informasi kejadian hujan hanya berdasarkan data kualitatif yang berhasil terkumpul di Posko selama berlangsungnya kegiatan TMC serta dari data TRMM, sedangkan data visibility diperoleh dari stasiun BMKG Bandara Sultan Thaha jambi.

\subsection{Informasi Hotspot (Titik Panas)}

\subsubsection{Analisis Temporal Hotspot}

Selama periode pelaksanaan kegiatan TMC sejak 07 September - 06 Oktober 2012, jumlah hotspot di wilayah di Propinsi Jambi berfluktuasi dengan jumlah maksimum 123 buah titik pada tanggal 18 September 2012. Distribusi hotspot secara temporal selama periode pelaksanaan kegiatan TMC tersaji dalam Gambar 6 berikut.

Sebelum kegiatan TMC dimulai, keberadaan hotspot di Propinsi Jambi sudah cukup banyak

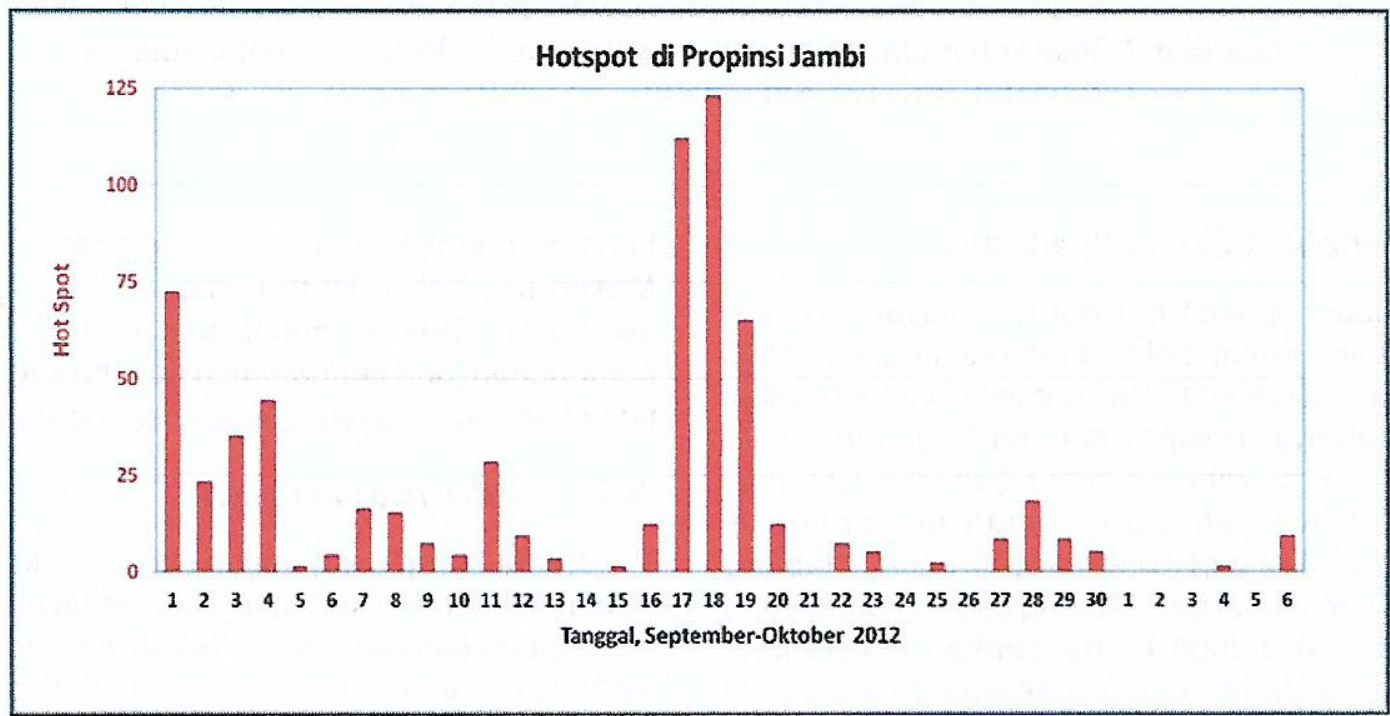

Gambar 6. Fluktuasi Jumlah Hotspot di Propinsi Jambi periode 01 September - 06 Oktober 
jumlahnya, ditambah dengan lokasi Jambi yang terletak di daerah konvergensi karena angin tenggara di wilayah ini menyebabkan kualitas udara di wilayah Propinsi Jambi mengalami penurunan akibat pekatnya kabut asap, Namun selama sepuluh hari pertama kegiatan jumlah hotspot berkurang cukup drastis. Pada tanggal 17 sampai dengan 19 September 2012 akumulasi hotspot mencapai jumlah terbanyak dikarenakan adanya aktivitas pembakaran lahan dan hutan yang masif akibat kondisi kering yang disebabkan oleh munculnya badai tropis SANBA.

Mulai dasarian ketiga bulan September 2012 sampai dengan dasarian pertama bulan Oktober 2012, hotspot Propinsi Jambi mulai jauh berkurang. Meskipun demikian kabut asap masih cukup pekatpada hari-hari tertentu. Pengamatan meteorologis pada bulan September dan awal Oktober 2012 menunjukkan bahwa angin global masih dominan dari arah Selatan - Tenggara, meskipun komponen baratan masih ada, sehingga diduga kondisi asap di wilayah Jambi dipengaruhi oleh wilayah di sebelah selatannya. Pada tanggal 06 Oktober 2012 kegiatan operasi TMC di wilayah Jambi dihentikan dan dilanjutkan di Propinsi Sumatera Selatan.

Secara administratif, sebaran hotspot terjadi pada hampir semua kabupaten di wilayah Propinsi Jambi. Selama operasi TMC tanggal 07 September - 06 Oktober 2012, di Kabupaten Tebo terdapat hotspot yang paling banyak (99 titik) disusul oleh Kabupaten Sarolangun (83), Kabupaten Muaro Jambi (70), Kabupaten Tanjung Jabung Timur (63), Kabupaten Tanjung Jabung Barat (46), Kabupaten Batang Hari (37), Kabupaten Merangin (32) dan Kabupaten Bungo (28).

Jumlah hotspot per kabupaten di wilayah Jambi selama kegiatan TMC disajikan dalam Gambar 7.

Kabupaten Muaro Jambi dan Tanjung Jabung Timur yang sebagian tanahnya berupa gambut dan posisinya dekat dengan kota Jambi mempunyai pengaruh yang kuat terhadap kepekatan asap di kota Jambi dan jarak pandang di bandara Sultan Thaha Jambi.

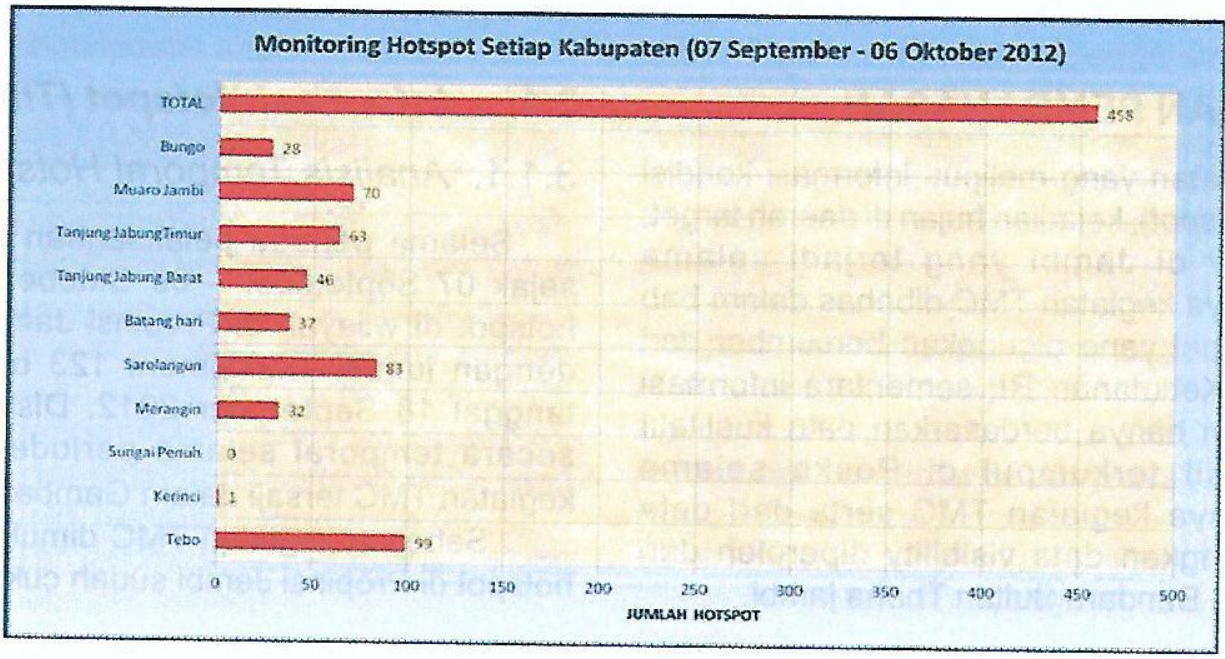

Gambar 7. Total keberadaan hotspot per Kabupaten di Propinsi Jambi, Selama kegiatan TMC (07 September - 06 Oktober 2012)

\subsubsection{Analisis Spasial Hotspot}

Distribusi spasial hotspot di Wilayah Propinsi Jambi secara umum selama periode kegiatan TMC terlihat pada Gambar 8. Dari gambar tersebut terlihat bahwa sebaran hotspot selama kegiatan cukup merata baik di wilayah timur (daerah gambut) maupun di wilayah barat (lahan perkebunan). Konsentrasi hotspot di wilayah Tanjung Jabung Timur, Muaro Jambi dan Tanjung Jabung Barat yang cukup merata diduga menyebabkan konsentrasi asap di kota Jambi cukup pekat pada saat saat tertentu. Selain itu karena wilayah tersebut merupakan daerah gambut maka keberadaan hotspot dalam satu titik dapat bertahan relatif lebih lama. Sedangkan konsentrasi hotspot di kabupaten Merangin, Tebo, Bungo dan Sarolangun yang sebagian besar merupakan daerah lahan perkebunan, dari pengamatan selama kegiatan TMC tidak berlangsung lama tetapi berpindah tempat.

\subsection{Informasi Hujan}

Pengukuran curah hujan selalu dilakukan pada saat pelaksanaan kegiatan TMC untuk mengetahui hasil pelaksanaan TMC. Selain jumlah hotspot, visibility dan indeks kualitas udara (IKU), data curah hujan merupakan salah satu parameter yang digunakan dalam evaluasi kegiatan Teknologi Modifikasi Cuaca karena dengan adanya kejadian 


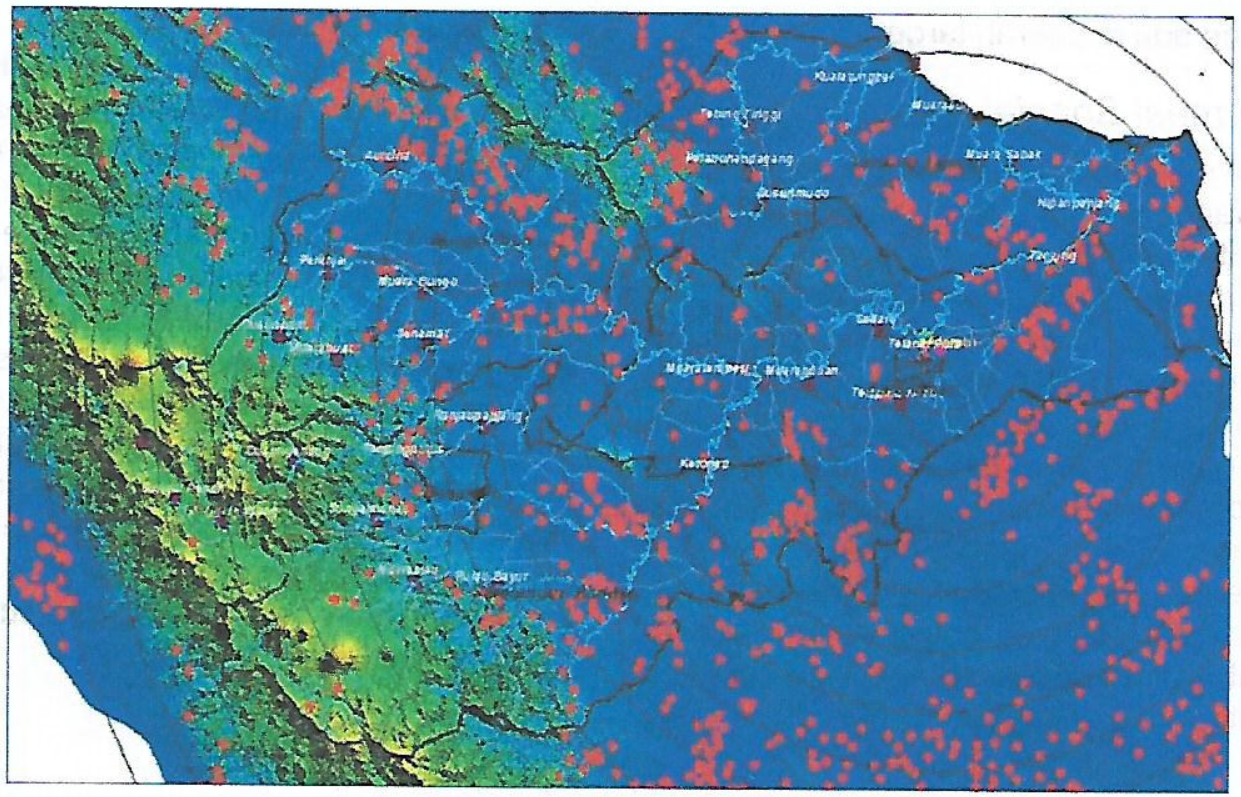

Gambar 8. Akumulasi Sebaran Hotspot Tanggal 07 September sd. 06 Oktober 2012

hujan diharapkan terjadi pengurangan kepekatan asap di atmosfer dan terjadi proses pembasahan permukaan tanah sehingga mengurangi potensi kebakaran lahan dan hutan.

\subsubsection{Kejadian Hujan Wilayah Jambi}

Selama kegiatan dilakukan pencatatan informasi kejadian hujan kuantitatif di stasiun penakar yang dikelola oleh stasiun klimatologi BMKG Propinsi Jambi. Sebanyak 24 (dua puluh empat) buah stasiun hujan yang tersebar di daerah Propinsi Jambi yang pengamatannya dikoordinasikan dengan stasiun Meteorologi Bandara Sultan Thaha dan BMKG wilayah Jambi. Pencatatan curah hujan dilakukan setiap hari mulai jam 00 UTC atau jam 07.00 pagi hari. Informasi curah hujan selengkapnya dapat dilihat pada Gambar 9.

Dari Gambar 9. dapat dilihat bahwa sejak awal kegiatan sampai akhir kegiatan di wilayah Propinsi Jambi terjadi hujan dengan intensitas bervariasi dari ringan sampai lebat, kecuali pada tanggal $13,16-$ 19, 26, 28 September hampir tidak ada kejadian hujan di wilayah target. Rerata curah hujan di Propinsi Jambi selama operasi TMC terjadi pada tanggal 6 Oktober 2012, sementara kejadian hujan tertinggi terjadi pada tanggal 12 September sebesar $159 \mathrm{~mm}$ di stasiun Jambi Luar Kota. Kejadian hujan juga terjadi di beberapa tempat lainnya seperti yang dilihat oleh Flight Scientist dari pesawat saat melaksanakan penyemaian awan, namun tidak diperoleh data kuantitatifnya karena keterbatasan stasiun curah

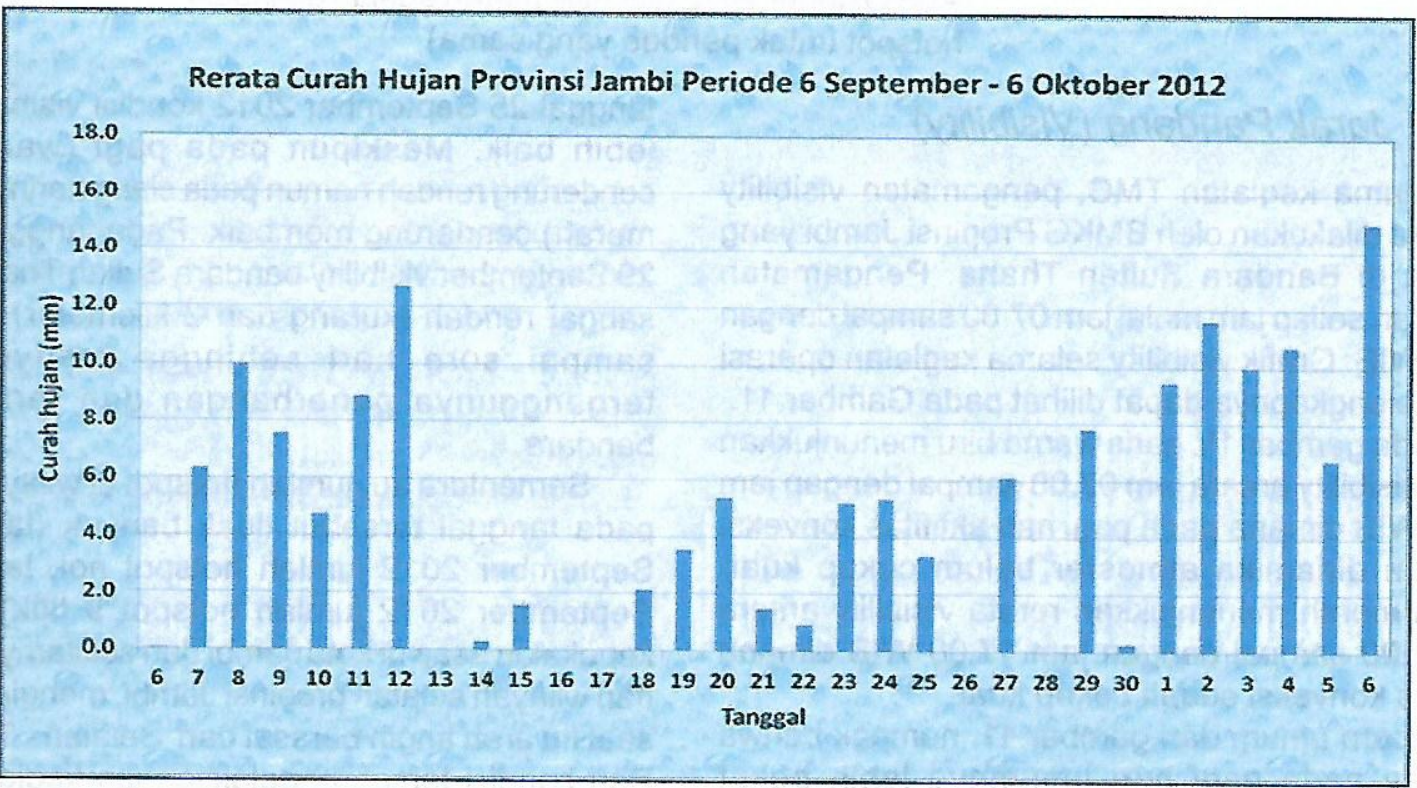

Gambar 9. Grafik curah hujan wilayah Jambi selama periode TMC (sumber : BMKG, Jambi) 
hujan yang ada di daerah target.

\subsubsection{Informasi Spasial Curah Hujan}

Informasi spasial curah hujan digunakan untuk melihat sebaran curah hujan di Propinsi Jambi. Selain dari stasiun BMKG Propinsi Jambi, data curah hujan (prisipitasi) dapat diakses dari TRMM (Tropical Rainfall Measuring Mission) di situs website. Kelebihan dari data TRMM adalah mempunyai nilai pada lokasi-lokasi yang tidak terukur oleh penakar hujan. Dengan melihat sebaran spasial dan keberadaan data curah hujan pengamatan yang tidak konsisten pada masing-masing stasiun di wilayah Jambi maka analisis spasial dilakukan menggunakan data TRMM. Peta sebaran curah hujan (isohyet) wilayah Jambi selama pelaksanaan TMC dari data TRMM disajikan pada Gambar 10.
Dari gambar di atas terlihat bahwa secara umum curah hujan di wilayah Jambi terkonsentrasi di Kabupaten Sarolangun dan Kabupaten Merangin dengan curah hujan hingga $100 \mathrm{~mm}$ dan di sekitar Kuala Tungkal Tanjung Jabung Barat. Di Kabupaten Tanjung Jabung Timur dan Kabupaten Muaro Jambi jumlah curah hujannya kurang dari $40 \mathrm{~mm}$. Jumlah curah hujan yang relatif kurang di kedua wilayah tersebut ditambah dengan akumulasi hotspot yang banyak menyebabkan kabut asap yang cukup pekat pada hari-hari tertentu yang pengaruhnya sampai di kota Jambi. Di wilayah Propinsi Jambi bagian barat meskipun jumlah hotspot banyak tetapi jumlah curah hujannya cukup besar sehingga masalah kepekatan kabut asap tidak begitu serius dibandingkan dengan di wilayah timur.

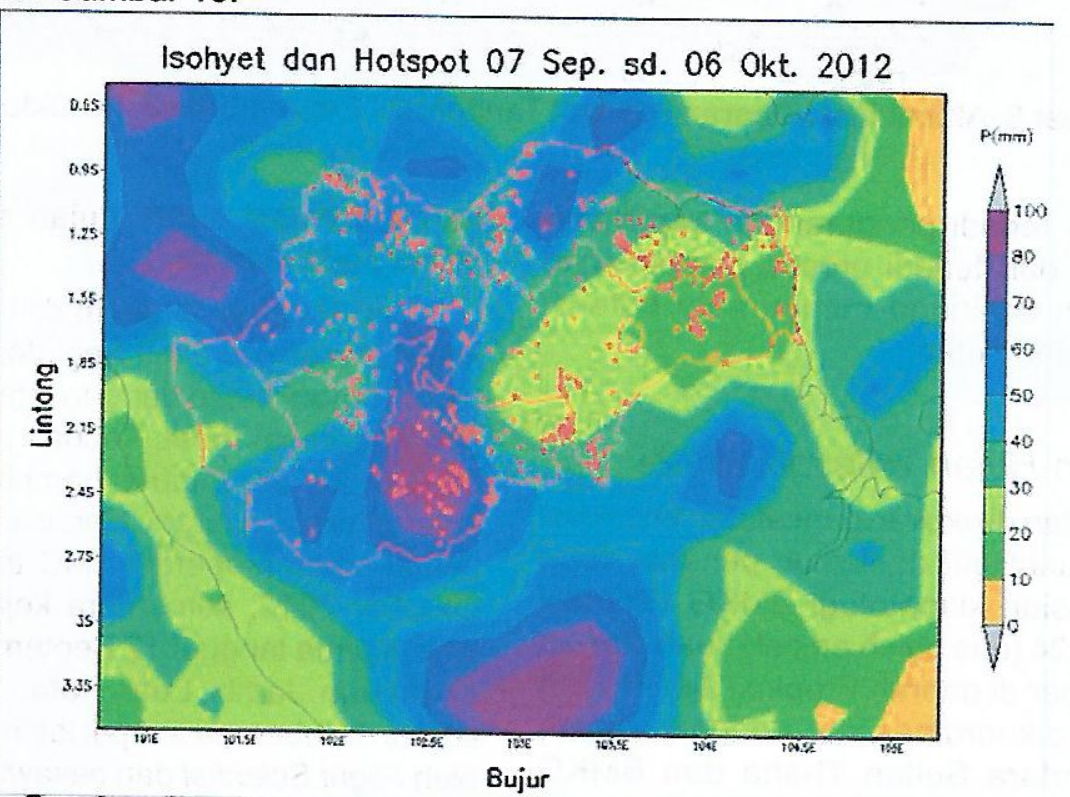

Gambar 10. Distribusi spasial curah hujan Propinsi Jambi darí data TRMM selama periode TMC (07 September - 06 Oktober 2012 (titik-titik merah adalah distribusi hotspot untuk periode yang sama)

\subsubsection{Jarak Pandang (Visibility)}

Selama kegiatan TMC, pengamatan visibility bandara dilakukan oleh BMKG Propinsi Jambi yang berada di Bandara Sultan Thaha. Pengamatan dilakukan setiap jam mulai jam 07.00 sampai dengan 17.00 WIB. Grafik visibility selama kegiatan operasi TMC selengkapnya dapat dilihat pada Gambar 11.

Pada gambar 11. garis warna biru menunjukkan rerata visibility antara jam 07.00 sampai dengan jam 10.00 WIB dimana pada pagi hari aktifitas konveksi ataupun dinamika atmosfer belum cukup kuat. Warna merah menunjukkan rerata visibility antara jam 11.00 sampai dengan jam 17.00 WIB dimana aktifitas konveksi sudah cukup kuat.

Secara umum dari gambar 11. nampak bahwa visibility pada pagi hari umumnya lebih pekat dibandingkan dengan siang hari. Dari Gambar tersebut menunjukkan bahwa sampai dengan tanggal 25 September 2012 kondisi visibility relatif lebih baik. Meskipun pada pagi (warna biru) cenderung rendah namun pada siang harinya (warna merah) cenderung membaik. Pada tanggal 26 dan 29 September visibility bandara Sultan Thaha Jambi sangat rendah (kurang dari 2 kilometer) dari pagi sampai sore hari sehingga menyebabkan terganggunya penerbangan dan tertutupnya bandara.

Sementara itu, jumlah hotspot di wilayah Jambi pada tanggal tersebut tidak banyak (tanggal 26 September 2012 jumlah hotspot nol, tanggal 29 September 2012 jumlah hotspot 9 titik). Diduga kepekatan asap di kota Jambi dan sekitarnya berasal dari wilayah selatan propinsi Jambi, mengingat pada saat itu arah angin berasal dari Selatan - Tenggara. Dari kondisi tersebut, pelaksanaan kegiatan TMC disarankan untuk dilanjutkan di Propinsi Sumatera Selatan. 


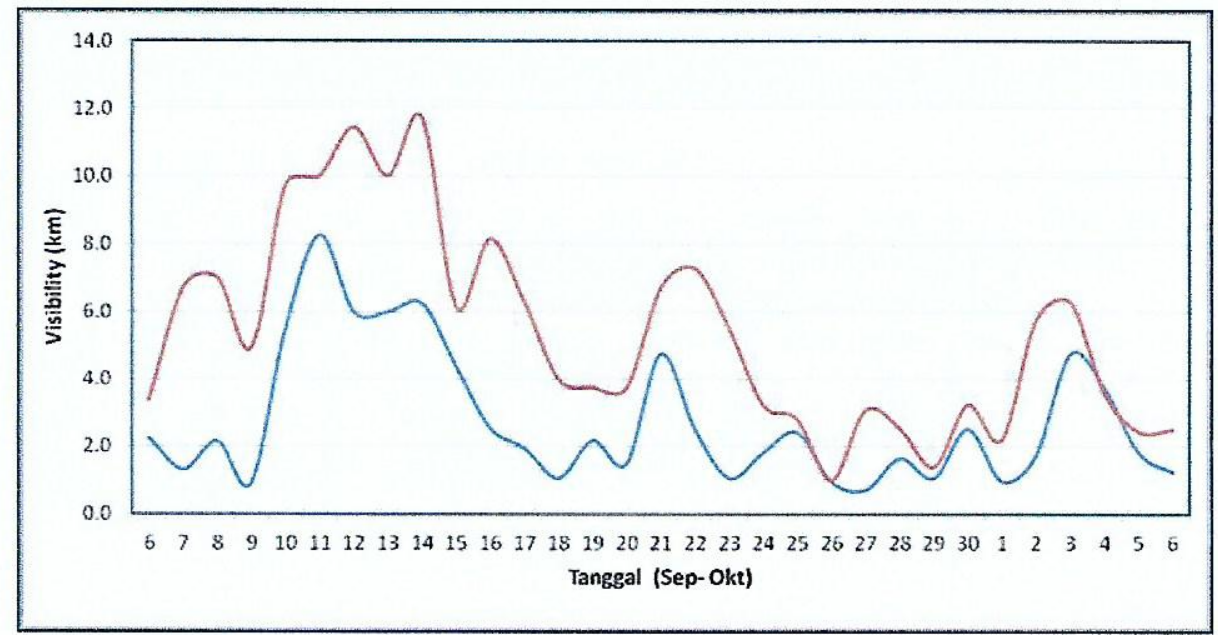

Gambar 11. Grafik rekapitulasi visibility di Bandara Sultan Thaha tanggal 07 September s.d. 06 Oktober 2012, warna biru adalah rerata jam 07.00-10.00 WIB; warna merah adalah rerata jam 11.00-17.00

\section{KESIMPULAN} WIB

Selama kegiatan TMC, hujan terjadi hampir setiap hari di berbagai tempat di wilayah Propinsi Jambi dengan intensitas yang bervariasi, sehingga diharapkan dapat digunakan untuk pembasahan tanah sehingga mengurangi jumlah hotspot.

Secara umum, kondisi hotspot selama kegiatan TMC mengalami penurunan dibandingkan dengan periode sebelum dilaksanakannya TMC (kecuali pada tanggal 17 sd. 19 September 2012). Namun demikian, terdapat fluktuasi jumlah hotspot yang terjadi akibat fluktuasi keberadaan awan dan aktifitas pembakaran lahan.

Pada akhir kegiatan, jumlah hotspot di wilayah Jambi sudah jauh berkurang, tetapi karena kondisi asap masih dirasa cukup pekat pada beberapa hari tertentu yang diduga berasal dari sebelah selatan dilanjutkan di Propinsi Sumatera Selatan.

\section{DAFTAR PUSTAKA}

Direktorat Pengendalian Kebakaran Hutan, Direktorat Jenderal PHKA Kementerian Kehutanan, 2012. Informasi Sebaran Hotspot, http://ditpkh-phka.dephut.go.id/

Matthew C. Wheeler and Harry H. Hendon, An AllSeason Real-Time Multivariate MJO Index: Development of an Index for Monitoring and Prediction, American Meteorological Society, 2004

UPT Hujan Buatan, Laporan Hasil Kegiatan Pemanfaatan Teknologi Modifikasi Cuaca (TMC) Untuk Menanggulangi Bencana Asap Kebakaran Lahan dan Hutan di Propinsi Jambi Tahun 2012. Jakarta, 2012.

World Meteorological Organization, EINino / La Nina Updated, June 2012. 